\title{
Importance of frailty assessment and management in elderly with aortic stenosis
}

\author{
Dimitra Kalimanovska-Oštrić1,2, Ivana Rakočević ${ }^{2}$ \\ ${ }^{1}$ University of Belgrade, School of Medicine, Belgrade, Serbia, ${ }^{2}$ Cardiology Clinic, Clinical Center of Serbia, \\ Belgrade, Serbia
}

Abstract

In developed countries aortic stenosis (AS) is the most common acquired valvular heart disease in elder population.

A 75 years old patient has been admitted to our institution due to symptomatic severe AS. Preoperative transthoracic echocardiography confirmed severe, calcified AS with a gradients of $95 / 49 \mathrm{mmHg}$, AVA $0.5 \mathrm{~cm} 2$ and moderate aortic regurgitation. Left ventricular ejection fraction was preserved. Preoperative coronary angiography and Duplex scan of carotid arteries excluded significant stenosis. Surgical risk assessed with EuroScore II was increased 5.9\%. In the presence of restricted mobility, significant frailty and other circumstances that may affect the rehabilitation, TAVI as an intervention mode would have been more suitable. Since this was not available, our patient underwent successful surgical aortic valve replacement. The first postoperative echocardiogram revealed normal function of the bileaflet mechanical valve $29 / 14 \mathrm{mmHg}$ with mild transvalvular regurgitation. Without any prior psychiatric disorders, patient after the operation experienced complete lack of energy and willingness to cooperate or to perform any daily activity so she remained immobile. The antidepressives were ineffective. The rehabilitation process was complicated with decubitus and Acinetobacter and Proteus mirrabilis in wound culture. After antibiotic treatment we had the appearance of diarrhea, severe hypoalbuminaemia and the global edemas progressed to anasarca This three monthslong and costly struggle of all cardiovascular practitioners and family unfortunately was unsuccessful. This case is one more confirmation that we need objective frailty assessment, as one of major risk factors in elderly with AS, before making definitive decision of interventional, either surgical or transcatheter treatment.

Key words Aortic stenosis, elderly, frailty, surgical aortic valve replacement

\section{Introduction}

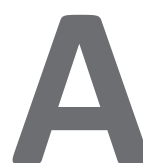

ortic stenosis (AS) is the most common acquired valvular heart disease (VHD) in well developed countries and is becoming more prevalent in populations over the age of 65 . It is commonly expressed in old-age as degenerative, calcific aortic valve disease. The only effective treatment is valve replacement since untreated, severe AS leads to diastolic and systolic left ventricular dysfunction and ultimately heart failure with life-threatening complications 1-3 The outcomes in elders with AS can be improved by optimal treatment of comorbidities and/or frailty as an overall marker of impaired functional, cognitive and nutritional status associated with increased risk for adverse effects after surgical or transcatheter interventions.

\section{Case report}

We report the case of a 75-year-old female patient, who was referred to our department for evaluation of chest pain, dyspnea and palpitations associated with an increase in troponin level (hs Tn $482 \mathrm{ng} / \mathrm{L}$ ). Three years earlier, the patient was diagnosed with severe aortic valve stenosis. Indicated surgery was postponed 3 times since she had multiple co-morbidities including hypertension, type 2 diabetes, bronchial asthma, chronic kidney disease, anaemia, and a history of paroxysmal atrial fibrillation and cerebral infarction. She was obese and poorly mobile.

Physical examination at admission revealed a 4/6 systolic murmur over the aortic area that radiated to the carotid arteries. There were no pathologic findings on lung auscultation. Blood pressure was 150/80 $\mathrm{mmHg}$.

Laboratory results showed elevated glucose and creatinine levels of $14.3 \mathrm{mmol} / \mathrm{L}$ and $243 \mathrm{umol} / \mathrm{L}$ respectively, as well as lower hemoglobin level of $100 \mathrm{~g} / \mathrm{L}$.

Electrocardiography initially showed sinus rhythm and voltage criteria for left ventricular hypertrophy. Onset of permanent atrial fibrillation occured a week later.

Preoperative transthoracic echocardiography (TTE) confirmed severe, calcified aortic stenosis with a peak 
transvalvular pressure gradient of $95 \mathrm{mmHg}$ (mean 49 $\mathrm{mmHg}$ ) and a calculated aortic valve area of $0.5 \mathrm{~cm}^{2}$ with moderate aortic regurgitation. Ascending aorta was dilated $(4.3 \mathrm{~mm})$. Left ventricular ejection fraction was preserved with normal left ventricular diametres $(5.1 \times 2.8 \mathrm{~cm})$. Left atrium was enlarged $(5.3 \times 7.6 \times 8.4 \mathrm{~cm})$ with moderate mitral regurgitation. Preoperative coronary angiography revealed completely normal coronary arteries. Duplex scan excluded significant stenoses of the carotid arteries. Spirometry confirmed obstructive pulmonary disease - FEV1 $85 \%$ of the predicted value.

Nephrologist and pulmonologist consulted in the preoperative work-up excluded absolute contraindications for the planned surgical procedure following adequate rehidration and a 3-day preventive therapy with $20 \mathrm{mg}$ pronison in addition to the rest preoperative therapy with Enoxaparin, Cardiopirin, Bisoprolol, Amiodaron, Fosinopril, Furosemid, Rosuvastatin, Aminophyline, Seretide inhaler, Insulin.

The latest ESC/EACTS guidelines for the management of valvular heart disease state that Intervention is indicated in symptomatic patients with severe, highgradient aortic stenosis (mean gradient $\geq 40 \mathrm{mmHg}$ or peak velocity $\geq 4.0 \mathrm{~m} / \mathrm{s}$ )( Class I level B)

In patients who are at increased surgical risk (STS or EuroSCORE II $>4 \%$ or logistic EuroSCORE I $>10 \%$ or other risk factors not included in these scores such as frailty, porcelain aorta, sequelae of chest radiation), the decision between SAVR and TAVI should be made by the Heart Team according to the individual patient characteristics, with TAVI being favored in elderly patients suitable for transfemoral access. (Class I, level B) .

Our 75 years old patient had symptomatic severe aortic stenosis. Surgical risk assessed with EuroScore II was increased, calculated $5.9 \%$. In the presence of restricted mobility and other conditions that may affect the rehabilitation process and significant frailty, TAVI as an intervention mode would have been more suitable. Since this alternative was not available, our patient underwent surgical aortic valve replacement as decided consilliary with our cardiac surgeons and anaesthesiologists (Heart team equivalent in our Institution).

The severely calcified stenotic aortic valve was excised and replaced with St Jude No 21 mechanical valve prosthesis. Early postoperative recovery was free of significant complications. She was extubated the first day after the procedure, with sufficient diuresis. There was no need for hemodialysis thereafter. The first postoperative echocardiogram revealed normal function of the bileaflet mechanical valve (PG $29 \mathrm{mmHg}$, MPG $14 \mathrm{mmHg}$ ) with mild transvalvular regurgitation. Diameters and ejection fraction of the hypertrophic left ventricle were normal (EF $70 \%$ ) with calcified mitral annulus and moderate mitral regurgitation in the dilated left atrium $(5.1 \times 7.2 \times 7.1 \mathrm{~cm})$. The right ventricle was normal-sized with moderate tricuspid regurgitation and indirectly assessed RVSP of $39 \mathrm{mmHg}$. There was no pericardial effusion even though a small right-side pleural effusion was detected.

Without prior remarkable psychiatric disorders, following the operation we witnessed complete lack of energy and willingness of our patient to cooperate. The patient was refusing to perform any daily activity and remained immobile in bed. The inclusion of antidepressive therapy for dysthymia suggested by a psychiatric was ineffective. The rehabilitation process was further complicated with a grade IV decubitus in the sacral area with isolated Acinetobacter and Proteus mirrabilis in wound culture. In order to prevent prosthetic endocarditis, we started high dosage antibiotic treatment in accordance to the antimicrobial susceptibilities. The appearance of diarrhoea was reason for adding metronidazole besides preventive fluconazole. Despite continuous diuretic therapy, in the setting of still preserved left ventricle ejection fraction, our patient started developing generalized edema. We associated them to marked hypoalbuminaemia that persisted even after intravenous application of at least 20 doses of albumins and a protein rich diet. In the absence of significant proteinuria, this was explained as a consequence of protein loss due to large decubitus ulcer and lymphorrhoea as the global edemas progressed to anasarca preventing even regular blood sampling and intravenous therapy. Furthermore, restricted mobility led to worsening of COPD. requiering intermittent corticosteroid and oxygen therapy. This three months-long and costly struggle of all cardiovascular practitioners, nurses, physiotherapeutics, numerous consulted organ-specific subspecialists and her family unfortunately seems useless.

\section{Discussion}

Aortic stenosis (AS) in elderly often exists with comorbid conditions, disability, polypharmacy, risk of falling and other changes in the body with aging which have complex and predominantly negative impact on morbidity and mortality. Frailty is defined as a syndrome of decreased physiologic reserve that a person has to tolerate stress associated with aging, disease and even therapy ${ }^{3}$. The prevalence of frailty ranges from $10 \%$ to $60 \%$ in older patients. It contributes to reported 3 -fold increase in post-operative mortality or major morbidity after valvular surgery.5.

The assessment of frailty should not be subjective, but rather rely on a combination of objective markers. The most frequently used has been the Fried frailty scale based on evaluation of slowness, weakness, low physical activity, exhaustion, and shrinking (unintentional weight loss) ${ }^{4}$. Diagnosis of frailty is based on the presence of $\geq 3$ of 5 criteria. In contrast to other timeconsuming frailty scales, 5-m gait speed can be used as a single and simple measure of frailty.

In the PARTNER trial, frailty was assessed using a composite of four markers (serum albumin, dominant hand grip strength, gait speed, and Katz activity of daily living (ADLs) survey), which were combined into a frailty score ${ }^{2}$. Outcomes measures were the time to death from any cause over 1 year of follow up and poor outcome at one year. Poor outcome was defined as: (1) death, (2) Kansas City Cardiomyopathy Questionnaire - Overall Summary score (KCCQ-OS) $<60$, or (3) decrease of $\geq 10$ points in the KCCQ-OS score from baseline to 1 
year. At 1 year, the Kaplan-Meier estimated all-cause mortality rate was $32.7 \%$ in the frail group and $15.9 \%$ in the non-frail group (log-rank $p=0.004)$. At 1 year, poor outcome occurred in $50.0 \%$ of the frail group and $31.5 \%$ of the non-frail group ( $p=0.02$ ). In conclusion, frailty was associated with increased mortality and a higher rate of poor outcome 1 year after TAVR. Considered as a safer alternative for patients at high risk of complications with open heart surgery, TAVR is not risk-free.

Frailty should not be viewed as a reason to withhold contemporary treatment and care but rather as an argument for delivering it in a more patient-centered fashion $^{6}$. Multidisciplinary approach including specialists for geriatric problems is of great importance when weighing the risks and benefits of interventional versus conservative treatment. Adverse outcomes in elders would be reduced by optimal treatment of the presenting VHD, comorbidities and frailty. Interventions to reduce frailty include cardiac rehabilitation (resistance and aerobic exercise), dietary counseling (caloric and protein support), and vitamin D supplementation advocated by experts in nutrition, physical function, cognition, psychogeriatrics and social support.

We report this case as an argument for objective frailty assessment as a major risk factor in elderly with AS that should be considered by the Heart team before reaching decision for interventional, either surgical or transcatheter treatment ${ }^{3-6}$. Equally important is to take into account patient's life expectancy, expected quality of life, patient preference as well as local resources ${ }^{1}$.

\section{References}

1. Helmut Baumgartner, Volkmar Falk, Jeroen J. Bax, et al: 2017 ESC/EACTS Guidelines for the management of valvular heart disease. The Task Force for the Management of Valvular Heart Disease of the European Society of Cardiology (ESC) and the European Association for Cardio-Thoracic Surgery (EACTS). European Heart Journal 2017; 38: 2739-2791.

2. Green P, Arnold SV, Cohen DJ, et al. Relation of Frailty to Outcomes After Transcatheter Aortic Valve Replacement (from the PARTNER Trial) . Am J Cardiol. 2015; 116 264-269.

3. Forman DE, Alexander KP. Frailty: A vital sign for older adults with cardiovascular disease. Can J Cardiol 2016; 32:1082-7.

4. Xue QL. The Frailty Syndrome: Definition and natural History. Clin Geriatr Med. 2011; 27: 1-15.

5. Afilalo J, Alexander KP, Mack MJ, et al. Frailty assessment in the cardiovascular care of older adults. J Am Coll Cardiol 2014; 63; 747-762.

6. Shinmura K. Cardiac senescence, heart failure and frailty: A triangle in elderly people. Keio J Med 2016; 65: 25-32.

\section{Sažetak}

\section{Primarna mitralna regurgitacija - ehokardiografska procena}

\section{Dimitra Kalimanovska-Oštrić, ${ }^{1,2}$, Ivana Rakočević ${ }^{2}$}

${ }^{1}$ Medicinski fakultet, Univerzitet u Beogradu, ${ }^{2}$ Klinika za kardiologiju, Klinički centar Srbije, Beograd, Srbija

U razvijenim zemljama Aortna stenoza (AS) je najčešće stečeno valvularno obolenje starije populacije. Bolesnica u starosnoj dobi od 75 godina je primljena u našu bolnicu zbog simptomatske, teške AS. Preoperativna transtorakalna ehokardiografija je potvrdila tešku, kalcifikantnu AS sa gradijentom 95/49 mmHg, AVA $0.5 \mathrm{~cm} 2$ i umerenom aortnom regurgitacijom. Globalna kontraktilna funkcija leve komore je bila očuvana. Preoperativna koronarografija i Doppler krvnih sudova vrata su bili uredni.

Rizik od hirurgije procenjen sa EuroScore II je bio povišen 5.9\%. Obzirom, na ograničenu pokretljivost, značajnu slabost i druge otežavajuće okolnosti za sprovođenje rehabilitacije, TAVI bi bio najadekvatnija terapijska procedura. Obzirom da nismo bili u mogućnosti sprovesti TAVI, kod bolesnika je učinjena hiruška zamena aortne valvule. Prvi postoperativni ehokardiogram je ukazao na urednu funkciju dvolisne mehaničke proteze sa $29 / 19 \mathrm{mmHg}$ gradijentima i lakom transvalvularnom regurgitacijom

lako bez preoperativnih psihijatrijskih poremećaja postoperativno kod bolesnice dolazi do potpunog gubitka energije, volje za sprovođenjem svakodnevnih aktivnosti, te je praktično celo vreme nepokretna. Antidepresivna terapija je bila u potpnosti neefikasna. Tokom rehabilitacije dolazi do razvoja decubitusa sa komplikacijama u vidu infekcije rane sa Acinetobacter i Proteus mirrabilis. Nakon uvođenja antibiotske terapije dolazi do pojave diareje, teške hipoalbuminemie, generalizovanih edema, a potom i anasarke. Ova teška tromesečna borba svih lekara i porodice je na kraju bila ne uspešna.

Ovaj prikaz slučaja ukazuje na neophodnu,objektivnu procenu stepena slabosti starijih pacijenata, kao jednog od glavnih rizik faktora za stariju populaciju sa AS, pre donošenja definitivne odluke o primeni načina lečenja bilo putem valvularne hirurgije ili TAVI procedure.

Ključne reči: Aortna stenoza, starije osobe, osetljiv pacijent, hiruška zamena aortnog zaliska 